\title{
Lukács: a reviravolta dos anos 1930 e a adoção da ontologia como expressão da filosofia de Marx
}

\author{
Rogério Castro ${ }^{1}$ \\ https://orcid.org/0000-0001-8134-7177 \\ ${ }^{1}$ Universidade Estadual do Ceará, Centro de Estudos Sociais Aplicados, Mestrado Acadêmico em Serviço Social, Trabalho e Questão \\ Social, Fortaleza, CE, Brasil
}

Lukács: a reviravolta dos anos 1930 e a adoção da ontologia como expressão da filosofia de Marx Resumo: O presente artigo visa apresentar o impacto que as mudanças no pensamento do filósofo György Lukács no começo dos anos 1930 tiveram no transcurso do seu itinerário intelectual. Além de destacar o sentido de toda a sua produção pós-1930, o texto intenta mostrar como - e por quais razões - o Lukács da maturidade irá adotar a palavra ontologia para expressar o substancial da filosofia de Marx.

Palavras-chave: Lukács. Marxismo. Ontologia.

Lukács: The turn of the 1930s and the adoption of ontology as an expression of Marx's philosophy Abstract: This article presents the impact that the changes in the thoughts of philosopher György Lukács in the early 1930s had on his intellectual itinerary. In addition to highlighting the meaning of all his post-1930 production, the article attempts to show how - and for what reasons - the later thoughts of Lukács adopt the word ontology to express the core of Marx's philosophy.

Keywords: Lukács. Marxism. Ontology.

Recebido em 01.10.2018. Aprovado em 20.11.2018. Revisado em 29.04.2019.

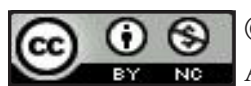

(C) O(s) Autor(es). 2019 Acesso Aberto Esta obra está licenciada sob os termos da Licença Creative Commons Atribuição-NãoComercial 4.0 Internacional (https://creativecommons.org/licenses/by-nc/4.0/deed.pt_BR), que permite copiar, distribuir e reproduzir em qualquer meio, bem como adaptar, transformar e criar a partir deste material, desde que para fins não comerciais e que você forneça o devido crédito aos autores e a fonte, insira um link para a Licença Creative Commons e indique se mudanças foram feitas. 


\section{Introdução}

O presente artigo tem como objetivo principal apresentar quando e por qual razão o filósofo György Lukács resolve referir-se à filosofia de Marx enquanto ontologia. Além de situar a questão no marco geral de sua obra, esse escrito localiza o entendimento de Marx do pensador húngaro no correspondente tempo histórico, o que se reveste de importância na medida em que há fissuras ao longo desse percurso, sem deixar de indicar a conexão dos problemas para os quais busca respostas com as polêmicas (e mais: dilemas, rumos etc.) do marxismo da respectiva época. Em resumo, além de tratar daquilo que virá a se chamar de (sua) visão madura da obra de Marx, esse texto tenta chamar a atenção para o exato período da adoção da expressão ontologia por Lukács e como tal escolha, feita somente em meados dos anos 1960, mantém, não obstante isso, estreita conexão com a concepção formada nos anos 1930-33.

Ademais, busca iluminar, ainda que de modo preliminar, as razões fundamentais que teriam levado o filósofo a adotar o termo ontologia. Sendo assim, intenta responder à questão levantada por estudiosos acerca do porquê Lukács ter escrito, nos últimos anos de sua vida, uma ontologia - e, por conseguinte, contrastar com críticos que negam ser a opção lukacsiana condizente com uma interpretação adequada sobre o pensamento marxiano.

Para alcançarmos os resultados, buscou-se observar a trajetória intelectual do autor a partir de uma visão ampla de sua obra. Isso permitiu não apenas uma visão de conjunto, mas possibilitou o rastreamento, por meio de uma leitura atenta dos respectivos escritos, das mudanças fundamentais na concepção do autor, em especial do momento em que a expressão ontologia é incorporada ao seu pensamento - e passa a ocupar correspondente lugar de destaque. Destarte, o texto é dividido em duas partes: primeiro, visa a apresentar o itinerário intelectual do filósofo com rigorosa observância aos respectivos contextos históricos (e o fio condutor que perpassa a sua concepção madura); na sequência, busca mostrar os motivos e o momento em que György Lukács passa a se servir da ontologia como expressão sintetizadora do núcleo central do legado de Marx.

\section{O caminho de Lukács até Marx}

György Lukács nasceu em Budapeste, na Hungria, em 1885. Filósofo, desde muito cedo desenvolveu uma peculiar predileção pelas artes e pela literatura. Decidido a seguir a carreira intelectual, volta as suas atenções para a intelectualidade germânica, em especial a filosofia. Nos anos de mocidade, frequenta aulas de George Simmel, muda-se para Heidelberg em 1912, integrando-se ao círculo do sociólogo Max Weber. O rigoroso esforço que faz para compreender a nova época engendrada com o advento do capitalismo pode ser auferido em duas de suas principais obras de juventude: A Alma e as Formas - 1911 - (LUKÁCS, 2015) e $A$ Teoria do Romance - 1920 - (LUKÁCS, 2000).

Com o estouro da Primeira Guerra em 1914, diferente de significativa parcela da intelectualidade da época, Lukács irá opor-se firmemente à conflagração. Convocado pelo serviço militar, o filósofo magiar retorna para a sua terra natal e passa a vivenciar o cada dia mais questionado feudalismo húngaro. Até então, Lukács, apesar de já ter lido Karl Marx, não era marxista. Segundo depoimento no Prefácio de 1967 ao livro História e Consciência de Classe - 1923 - (LUKÁCS, 2003) seu pensamento era constituído por um amálgama internamente contraditório de teorias. Com a evolução dos acontecimentos em seu país, o filósofo irá aderir ao Partido Comunista húngaro no final de 1918 e, a partir de março de 1919, participará ativamente da República Húngara dos Conselhos. Após a sua derrubada, sucedem-se anos de aprendizagem em seu exílio em Viena, tanto por meio de estudos como através da aguerrida militância partidária. Em avaliação posterior, o autor de Para uma Ontologia do Ser Social (LUKÁCS, 2012, 2013) informa que os anos 1920 foram anos de afastamento progressivo do sectarismo messiânico. Após as Teses de Blum (LUKÁCS, 1980), em 1929, a reviravolta final em seu pensamento tomará corpo na União Soviética, no começo dos anos 1930. Ao seu juízo, estaria se completando o terminus ad quem de sua assimilação do marxismo, inaugurando, com isso, uma nova fase do seu longo itinerário intelectual, também chamada de fase madura do seu pensamento.

\section{Os germes para desenvolver o legado de Marx e o renascimento do marxismo}

Em 1930, durante a sua primeira estada na União Soviética, Lukács vai tomar parte do debate sobre filosofia que tinha sido aberto por Stalin. Embora as intenções deste último fossem minar a influência de Plekhanov (tido como um mediador de Marx), afirmando ser a linha correta a Marx-Lenin, o filósofo húngaro vai afirmar que esse debate iria despertá-lo para outro problema. Isso porque tanto o russo Plekhanov quanto o alemão Mehring estavam convencidos de que a teoria marxiana se tratava unicamente de uma teoria econô- 
mico-social. Em sendo assim, diziam eles, era necessário completar a filosofia de Marx naquilo que ela não dava conta, como a estética. "Plekhanov e Mehring achavam que era necessário completar Marx quando eram debatidas questões diversas das econômico-sociais. [...] Mehring insere a estética kantiana na teoria de Marx, e Plekhanov, uma estética em substância positivista", explica Lukács (1999, p. 87, grifo nosso).

Contrário a essa visão, o filósofo vai defender que o marxismo é uma concepção universal do mundo, não sendo necessário que outras teorias lhe sejam apensadas. Ao lado de M. Lifschitz, seu colega de trabalho no Instituto Marx-Engels de Moscou, Lukács irá começar a desenvolver tais ideias. "[...] o fato é que fomos os primeiros a falar de uma estética marxiana específica, e não desta ou daquela estética que completasse o sistema de Marx". (LUKÁCS, 1999, p. 88, grifo nosso). Como mencionamos, os anos de 1930-31 será um ano de grandes transformações no pensamento do autor, graças às descobertas feitas por ele ao ler os inéditos Manuscritos Econômico-Filosóficos ${ }^{1}$ - 1844 - (MARX, 2004). A sua amizade e a fecunda convivência intelectual com Lifschitz, conforme descreve o próprio autor húngaro no Prefácio de 1967 (LUKÁCS, 2003), iria fazer com que o autor se convencesse de que estaria no próprio corpo da obra de Marx, e não fora dela, os princípios para se desenvolver uma estética de natureza marxista.

Depois de muitas conversas, tornou-se claro para ambos que mesmo os melhores e mais capacitados marxistas, como Plekhanov e Mehring, não haviam apreendido com suficiente profundidade $o$ caráter universal da concepção de mundo do marxismo e, por isso, não compreenderam que Marx também nos coloca a tarefa de edificar uma estética sistemática sobre um fundamento dialético-materialista. (LUKÁCS, 2003, p. 47, grifo nosso).

Lukács se encontrava ébrio de entusiasmo com as descobertas feitas durante a sua primeira estância em Moscou, tal qual aquelas que fizera no Instituto Marx-Engels, e, desde então, pôs-se a trabalhar no material disponível com o intuito de atestar (ou não) a veracidade das hipóteses dele e do amigo Lifschitz a saber, encontrar nos escritos marxianos e engelsianos elementos que referendassem a existência de uma concepção de estética nos fundadores do materialismo-dialético. O primeiro resultado desse esforço é do ano de 1931. Trata-se do ensaio O Debate sobre Sickingen entre Marx-Engels e Lassale (LUCKÁCS, 2016), no qual o filósofo analisa as cartas trocadas entre o texto do autor do Sickingen e os dois filósofos alemães, que será publicado em Moscou no ano de 1933. Na entrevista concedida em 1971 para a sua autobiografia em diálogo, ele assevera: "A idéia de que a estética seja uma parte orgânica do sistema marxiano está presente no artigo que escrevi a respeito do debate sobre Sickingen entre Marx e Lassalle [...]" (LUKÁCS, 1999, p. 88). A sua produção dos anos 1930 não deixa dúvidas quanto ao interesse renovado pela questão da estética ${ }^{2}$. Além de participar como membro ativo da revista Literaturni Kritik entre os anos de 1934-39, indica o aprofundamento das pesquisas estéticas nos escritos de Marx e Engels o ensaio de 1935, Friedrich Engels como Teórico e Crítico Literário (LUCKÁCS, 2016), o de 1938, Marx e o Problema da Decadência Ideológica (LUCKÁCS, 2016), e, por fim, o ensaio do ano de 1940, Tribuno do Povo ou Burocrata? (LUCKÁCS, 2016) ${ }^{3}$. Junte-se a isso a redação da sua obra de fôlego, O Romance Histórico ${ }^{4}$ (LUKÁCS, 2011b), escrita entre os anos de 1936-37 e publicada em russo no ano de 1937 - ou seja, no tenebroso período dos processos.

Faz parte do repertório das investigações lukacsianas dos escritos de Marx em busca de extrair deles uma concepção marxista de estética (i.e., neles contida) o ensaio do ano de 1934, Karl Marx e Friedrich Theodor Vischer, onde Lukács analisa os extratos que Marx teria tomado da Estética de Vischer (LUKÁCS, 2016). Ao retornar para a União Soviética em março/abril de 1933, após curta temporada em Berlim, Lukács se depara com uma campanha, aberta por Stalin, contra a Associação Russa dos Escritores Proletários (RAPP), presidida pelo trotskista Auerbach. O interesse de Stalin era unicamente o de neutralizar o presidente trotskista da RAPP. Os críticos da Associação, como Judin e Usievic, reivindicavam a criação de uma associação geral dos escritores soviéticos, ao contrário da RAPP, que só admitia aqueles que se declarassem proletários. Lukács vai aderir a esse movimento, do qual a revista (quer dizer, a ala não puramente stalinista do movimento) Literaturnyj Kritik será resultado, posto que tal publicação intencionava combater as tendências rappistas. Diga-se de passagem, teria sido graças às concessões obtidas para a revista por meio de Elena Usievich, que tinha relações com membros do Comitê Central do Partido Comunista da União Soviética (PCUS) - Mitin e Judin, ambos filósofos - que o marxista húngaro julga ter sido poupado dos processos de 1936-37. "Ela [Usievic], por sua vez, tinha boas relações de amizade com Judin. Assim, trabalhávamos como uma facção no Comitê Central [...] estávamos também sob a proteção de Judin"s (LUKÁCS, 1999, p. 99), analisa ele no Pensamento Vivido. Em 1932, a RAPP será dissolvida e, dois anos mais tarde, aparecerá uma união de escritores de todas as tendências e ideologias (o aparelho stalinista não tardaria, apesar de um breve período intermediário, a reestabelecer o domínio da tendência sectária em literatura ${ }^{6}$ ). Entre os escritos desse período de 1934 a 1940 
(ano em que Literaturnyj Kritik tem suas atividades encerradas), destacam-se: Narrar ou Descrever? Uma Discussão sobre Naturalismo e Formalismo, do ano de 1936 (LUKÁCS, 2010a); A Fisionomia Intelectual dos Personagens Artísticos, também do ano de 1936 (LUKÁCS, 2010a); e O Escritor e o Crítico, de 1939 (LUKÁCS, 2010a). Há ainda ensaios que versam diretamente sobre trabalhos literários: Balzac: Les Illusions Perdues e A Polêmica entre Balzac e Stendhal, ambos do ano de 1935 (LUKÁCS, 1968b).

Mas não era apenas no domínio da estética que a produção lukacsiana dos anos 1930 se concentrava. A profusão criadora do pensador magiar ia além e podia ser atestada com a conclusão, no outono de 1937, da primeira versão do seu livro O Jovem Hegel (LUKÁCS, 2018a). É nessa época também que ele inicia os seus trabalhos de outra obra de grande envergadura, A Destruição da Razão ${ }^{8}$ (LUKÁCS, 1968a) - que, no geral, fora escrita durante a Segunda Grande Guerra. Enquanto o seu trabalho sobre Hegel divergia da linha oficial segundo a qual o autor da Fenomenologia do Espírito (HEGEL, 2003) era o ideólogo da reação feudal contra a Revolução Francesa9 (estando aqui, sem mais, as razões de tal publicação se dar apenas dez anos mais tarde e por meio de uma editora suíça), seu livro $A$ Destruição da Razão (LUKÁCS, 1968a) se opunha à concepção defendida por Stalin e Zdanov, em que toda a história da filosofia é apresentada como a luta entre materialismo e idealismo, ao pôr no centro das atenções a oposição entre filosofia racional e irracional ${ }^{10}$. "É verdade que os irracionalistas eram todos idealistas, mas eles também tinham antagonistas racionalistas-idealistas" (LUKÁCS, 1999, p. 103), diz ele em sua autobiografia em diálogo.

Lukács estava com 48 anos quando sentia pisar em terreno firme em matéria de marxismo ${ }^{11}$ (quando ingressava no Partido Comunista húngaro em 1918, ele estava com 33 anos). O filósofo húngaro estava em Berlim quando Hitler fora alçado ao poder em 30 de janeiro de 1933. Além de testemunhar a ascensão das forças reacionárias do nacional-socialismo na Alemanha, dois meses mais tarde o pensador marxista iria regressar para uma estância de mais de uma década no bastião do socialismo internacional, a União Soviética. No entanto, a contrário do refúgio seguro, o filósofo comunista vai encontrar uma atmosfera ascendentemente hostil, com o recrudescimento do regime stalinista, e sobreviverá, segundo as suas próprias palavras, a uma das maiores campanhas de prisões do mundo. Com a ascensão do nazifascismo, diminuía as chances do filósofo, visto que, se Hitler tomara a Alemanha, na sua Hungria o regime de Horthy também não lhe daria opção. Logo, será sob as condições severas do stalinismo (e da luta antifascista), que Lukács irá, ébrio de entusiasmo, dedicar-se à tarefa de edificar uma estética marxista sistemática, bem como a outros trabalhos filosóficos no espírito das suas novas descobertas que punham abaixo a antiga concepção de História e Consciência de Classe (LUKÁCS, 2003).

A ideia de que a estética seja uma parte orgânica do sistema marxiano está presente no artigo que escrevi a respeito do debate sobre Sickingen entre Marx e Lassalle; em Lifschitz esta idéia está no seu livro, escrito na juventude, sobre o jovem Marx. Sobre esta base começamos a desenvolver a ideia de que existe uma estética marxiana e que para desenvolvê-la era necessário partir de Marx. (LUKÁCS, 1999, p. 88, grifo nosso).

Ao contrário de outras ideias dos dois intelectuais marxistas, essa concepção fora rapidamente difundida na União Soviética (evidentemente que por conta de tal visão ser funcional à luta staliniana contra o pensamento de Plekhanov, que defendia a ideia de completar Marx). Convencidos de que Marx legara uma concepção universal de mundo, Lukács e Lifschitz (LUKÁCS, 2000) passam a defender que, ao contrário dos autores que reduziam a herança marxiana a uma teoria econômico-social (Mehring e Plekhanov), não haveria de se recorrer a outras matrizes teórico-filosóficas para se obter uma estética de caráter marxista. Para este fim, bastava buscar as anotações e referências estéticas na própria obra do filósofo alemão (e de Engels). Destarte, concluem Lukács e Lifschitz que é possível desenvolver uma estética marxiana, mas desde que se institua como ponto de partida o próprio Marx ${ }^{12}$.

Mas o entusiasmo lukacsiano não ficara restrito aos anos 1930 e ao período da Segunda Grande Guerra. Ao analisar os efeitos devastadores do predomínio intelectual staliniano sobre a vida científica, para o desenvolvimento do marxismo (a economia política e a filosofia), o autor húngaro não irá esmorecer e, após a morte de Stalin em 1953 e a realização do XX Congresso do PCUS em 1956, indicará um tertium datur que, ao mesmo tempo, extirpasse o dogmatismo esquemático de cunho stalinista e combatesse a maior ameaça ao marxismo em sua compreensão, as tendências que pregavam a sua revisão. Nesse escrito redigido em 1957, um ano depois de o XX Congresso do PCUS denunciar o sistema do culto à personalidade, ele aponta não apenas o caminho para a superação da paralisia da pesquisa marxista, como também deixa assinalado que a herança marxiana, utilizada para o progresso do próprio marxismo, transcende a esfera da arte:

Somente se tivermos consciência de que o marxismo nos legou um método seguro, um extraordinário elenco de sólidas verdades, uma enorme quantidade de sugestões muito fecundas para o seu próprio 
desenvolvimento; se tivermos clareza de que não poderemos fazer nenhum progresso real no caminho da ciência sem uma assimilação e uma experimentação aprofundada destes princípios; se tivermos convicção de que a elaboração de ciências universais com base no marxismo é uma tarefa a realizar e não algo já solucionado; se tudo isto for lucidamente compreendido, então haverá uma retomada da pesquisa marxista. (LUKÁCS, 2008, p. 50, grifo nosso).

De acordo com o filósofo, Lenin e o próprio Engels, antes de morrerem, já haviam indicado essa tarefa. O líder soviético, por exemplo, teria empreendido uma reforma do marxismo demonstrando como a obra de Marx e Engels era rica em noções até então desconhecidas ${ }^{13}$; além disso, refutou aqueles que, diante dos novos problemas da vida, apelavam sempre para as infaliveis citações ${ }^{14}$. Destarte, será no contexto pósmorte de Stálin que Lukács, diante da paralisia à qual a pesquisa marxista fora submetida, irá renovar as esperanças em prol da luta por um novo caminho. Em resumo, um caminho que faça florescer o trabalho científico de caráter marxista: "Quando dizemos: não temos ainda uma lógica, uma estética, uma ética, uma psicologia marxistas, não estamos dizendo nada que leve ao desânimo. [...] falamos com paixão, plena de esperança, dos grandiosos e entusiasmantes desafios científicos [...]" (LUKÁCS, 2008, p. 50). Aqui, aliás, ganha pleno sentido o esforço e a produção intelectual posterior do autor - o seu trabalho sobre estética e o plano de escrever uma ética ${ }^{15}$.

Em seu György Lukács, Filosofo Autonomo, T. Szabó (2005, p. 120, tradução nossa) explica o contexto em que Lukács começa a falar num renascimento do marxismo:

[...] depois do XX Congresso do PCUS, Lukács muda a postura (torna-se muito mais direto porque considera que a sua vida já não está em perigo) e, enquanto as reformas econômicas de Kádár entram em vigor, assume uma posição de abertura otimista em relação ao desenvolvimento da teoria. Precisamente neste clima favorável começa a falar do renascimento do marxismo que, do seu ponto de vista, significava um retorno ao jovem Marx. E neste clima novo, mesmo perseverando em alguma posição, abandonou o vocabulário da Inquisição.

Numa entrevista concedida ao filósofo brasileiro Leandro Konder, no ano de 1969 (PINASSI; LESSA, 2002) , Lukács se queixa da não publicação de todos os materiais e escritos de K. Marx - fato que, segundo ele, ajudaria a dirimir controvérsias entre estudiosos do pensador alemão naquela quadra em que se observava um renascimento do marxismo. Em seguida, após ser indagado sobre o que constituiria esse renascimento, o filósofo explica que se trata de um processo já iniciado, dando a entender que, em função do espírito de enrijecimento da era Stalin, a pesquisa marxista fora obstaculizada e, por conseguinte, o desenvolvimento histórico do marxismo igualmente interditado (PINASSI; LESSA, 2002). Por conta disso, as grandes mudanças sofridas pelo capitalismo daquela quadra histórica - explica o pensador - careciam duma análise marxista, tal qual “[...] à que Marx fez do capitalismo de seu tempo ou à que Lenin fez do imperialismo na época da Guerra de 1914". (PINASSI; LESSA, 2002, p. 127-128) ${ }^{16}$. Ao defender a importância da elaboração da ontologia do marxismo para o enfrentamento dos equívocos difundidos pela filosofia de então, Lukács cita (PINASSI; LESSA, 2002), como exemplo de tendência irracionalista, as teorias desenvolvidas por Herbert Marcuse ${ }^{17}$.

Não obstante enfatizasse, como dirá István Eörsi, a necessidade de reforma e renascimento do marxismo e defendesse o lema Retorno a Marx! (LUKÁCS, 1999), três décadas após a sua morte, Paulo Netto (2002) avaliou como falho o prognóstico do filósofo que previa o renascimento do marxismo. Considerandoo como um exilado do mundo da cultura contemporânea, ausência que fará o pensador brasileiro designá-la de terceiro exílio, Paulo Netto (2002, p. 78) avalia que o professor de Budapeste morrera iludido pelo seu renitente otimismo histórico: "[...] ao contrário das suas expectativas, o poder de imantação da tradição marxista encontra-se extremamente debilitado mesmo entre os produtores culturais mais influentes que se pretendem críticos em face da ordem burguesa no seu presente estágio [...]”. De todo modo, se considerarmos que uma das condições para o renascimento do marxismo seja o estado livre de antolhos dogmáticos, é justo manter a crença de que uma tal retomada possa ter lugar, posto que - inclusive - é dessa pesquisa original, tal como a de extração lukacsiana, que pode vir a florescer um autêntico desenvolvimento do marxismo (edificado, vale dizer, a partir do elenco de sólidas verdades legado pelo próprio Marx).

\section{A adoção da ontologia como expressão da filosofia de Marx}

Desde 1945, Lukács havia regressado para a Hungria. Neste mesmo ano, ele lança o livro Literatura e Democracia. Além de ser indicativo da continuidade dos estudos estéticos (em particular, a crítica literária) pelo 
autor, esse trabalho tinha o propósito de extrair da nova situação inaugurada com o término da guerra as devidas consequências, que, segundo o filósofo, exigia uma transição ao socialismo de modo gradual, à base do convencimento. A repercussão estrondosa do seu livro o impeliria a uma nova autocrítica - ele sentiu-se obrigado a adotar uma postura semelhante após a repercussão negativa das chamadas Teses de Blum (LUKÁCS, 1980), do ano de 1929. Por sua vez, as discussões que o trabalho desencadeara permitiriam que ficasse mais clara para ele a contradição entre o fundamento novo (inaugurado pela nova situação do pós-guerra) e a velha ideologia (retorno aos métodos dos grandes processos). Lukács estava convencido de que, diante da nova ordem mundial, uma nova tática e uma nova estratégia se faziam necessárias, mas, incorrendo no mesmo erro de leitura protagonizado por Stálin no final dos anos 1920 - “[...] socialdemocracia como "irmã gêmea” do fascismo [...]” (LUKÁCS, 2008, p. 47) - a nova situação acabaria sendo enfrentada com uma estratégia e uma tática antigas, que conduziria, por exemplo, a ruptura da União Soviética com a Iugoslávia. Escreve ele em 1957:

[...] embora já na segunda metade dos anos 1920 a luta contra o fascismo se tivesse tornado o problema central, Stalin só compreendeu o seu significado dez anos depois. Numa conjuntura em que a formação de uma frente única dos trabalhadores - ou melhor, de todas as forças democráticas - era questão vital para a civilização, a tese de Stalin segundo a qual a socialdemocracia era a "irmã-gêmea" do fascismo inviabilizou aquela frente. Portanto, ele permaneceu preso a uma estratégia e a uma tática justas na tempestade revolucionária de 1917 e logo depois, mas que, com o refluxo desta tempestade, [...] tornaram-se inteiramente anacrônicas no plano objetivo. Comecei a considerar o que ocorreu depois de 1948 como a repetição histórica do erro fundamental dos anos 1920. (LUKÁCS, 2008, p. 46-47).

A referência ao ano de 1948 era em função da revolução na China. De acordo com o pensador húngaro, a vitória proletária chinesa punha um elemento novo na cena mundial, posto que, com o advento de mais um país socialista, a União Soviética deixava a condição de isolamento. A maior inflexão da história desde 1917, defende, colocava o período do socialismo em um só país ${ }^{18}$ definitivamente no passado. Apesar destas transformações, Stalin e seus seguidores, do ponto de vista subjetivo, optaram por não tirar da realidade completamente transformada as devidas consequências teóricas e práticas ${ }^{19}$. Após um breve período de ampla liberdade (1945-1948), no ano de 1949 é aberto o Debate Lukács por László Rudas, no qual o filósofo húngaro é acusado de "[...] cosmopolitismo, revisionismo [...]", de ter praticado "[...] desvios de direita [...]" e ainda ter se tornado um "[...] serviçal do imperialismo [...]" (LUKÁCS, 2008, p. 214). Sentindo a necessidade de empreender um recuo tático, Lukács assim o faz, mas, avalia na sequência, que a sua saída forçada de cena traria a vantagem de poder concentrar-se com afinco nos trabalhos intelectuais. Já no começo dos anos 1950, por exemplo, ele conclui a redação de uma de suas mais importantes obras da fase madura, $A$ Destruição da Razão (LUKÁCS, 1968a), publicada em alemão em 1953.

A morte de Stalin, em 1953, e a denúncia do sistema de culto à personalidade proferida no XX Congresso do PCUS, em fevereiro de 1956, abririam novas possibilidades diante do espírito de enrijecimento reinante. Em outubro de 1956, irrompe o levante húngaro - na avaliação do filósofo, um grande movimento espontâneo. Depois de ser eleito para o Comitê Central, Lukács assumirá o cargo de ministro da Cultura. Ele votará contra a saída do Pacto de Varsóvia, posição defendida por Imre Nagy e que iria prevalecer. Com a chegada das tropas soviéticas em 4 de novembro, o filósofo será deportado para a Romênia, de onde retornará apenas em abril de 1957. É de Bucareste, na Romênia, que ele irá redigir o Prefácio ao seu trabalho Introdução a uma Estética Marxista: sobre a categoria da particularidade ${ }^{20}$ (LUKÁCS, 1978), um resultado das suas rigorosas investigações no campo da estética e uma mostra inequívoca da continuidade da linha assumida e desenvolvida desde 1930.

No ano de 1960, os originais da primeira parte da Estética (LUKÁCS, 1982) haviam sido concluídos e enviados para a tipografia ${ }^{21}$ (na nota de apresentação ao seu Existencialismo ou Marxismo? (LUKÁCS, 1967), de 11 de abril de 1960, o autor informa estar acabando a sua estética e reitera que iniciará, assim que terminar o trabalho que então lhe consumia, o seu estudo sobre ética, onde também, continua, pretende voltar aos problemas da filosofia de Sartre ${ }^{22}$ ). Inicialmente pensada em duas partes, como anunciou no prefácio de três anos antes, o projeto ganharia uma terceira e o nome que veio a ter quando da sua publicação em 1963, Estética (LUKÁCS, 1982), diferente do título inicial anunciado no inverno de 1957, Problemas do Reflexo Estético. Já no pós-escrito de 1957, Meu Caminho para Marx (LUKÁCS, 2008) o filósofo informava estar concentrado no seu trabalho sobre estética, cuja primeira parte viria a público seis anos depois em quatro volumes, e anunciava também, no marco do seu entusiasmo de desenvolver o marxismo, o projeto de escrever uma ética.

Aos 75 anos de idade, Lukács desincumbiu-se da primeira parte do projeto de três partes de sua estética e lançou-se na segunda empreitada, inicialmente pensada para ser um trabalho especificamente sobre ética. No curso dos estudos deste último projeto irá se dar conta da necessidade de fundar a sua discussão sobre 
ética no terreno da realidade e tal esforço irá se transformar numa espécie de obra introdutória à ética. $\mathrm{O}$ material se transforma num monumental empreendimento de 1.200 páginas e que, deixado na forma de manuscrito, viria à lume apenas postumamente, uma vez que o filósofo virá a falecer a 4 de junho de 1971, i. e., antes de concluí-la. O título que esse seu último trabalho, dividido em dois volumes, recebe é Para uma Ontologia do Ser Social23 (LUKÁCS, 2012, 2013) - o filósofo teria concluído no outono de 1970 um prolegomenon a essa obra (LUKÁCS, 2010b). Em sua autobiografia em diálogo, do ano de 1971, ele (LUKÁCS, 1999, p. 139) explica: "Na verdade eu planejei a Ontologia como fundamento filosófico da Ética, e nesse sentido a Ética foi suplantada pela Ontologia, já que se trata da estrutura da efetividade e não de uma forma separada".

Até os anos 1960, Lukács nunca havia se referido à

Ademais, busca iluminar, ainda que de modo preliminar, as razões fundamentais que teriam levado o filósofo a adotar o termo ontologia. Sendo assim, intenta responder à questão levantada por estudiosos acerca do porquê Lukács ter escrito, nos últimos anos de sua vida, uma ontologia - e, por conseguinte, contrastar com críticos que negam ser a opção lukacsiana condizente com uma interpretação adequada sobre o pensamento
marxiano. acerca da possibilidade de uma ontologia marxista. E as suas dúvidas - vocalizadas por intermédio de Holzpoderiam ser da seguinte forma sintetizadas: "Que sentido pode ter o termo 'ontologia' numa filosofia marxista?" (LUKÁCS, 2014, p. 23) Certos de que sob o prisma marxista a ontologia era resolvida na sociologia, os estudantes mostravam-se inquietos quanto ao uso de tal palavra para referir-se aos princípios de Marx, visto que tal expressão vai além das categorias histórico-sociais, transcende os domínios da história e da economia. Nisso se constituía a inquietude dos alunos. A resposta do filósofo húngaro será amparada na premissa marxiana segundo a qual apenas existe uma ciência unitária, a ciência da história. Desdobrando o significado dessa afirmação, no entendimento lukacsiano de Marx sociedade e natureza não seriam antíteses que se excluem; ao contrário, elas estariam em relação recíproca. Não seria por outro motivo que Lukács iniciaria a sua resposta afirmando ser preciso começar pela vida cotidiana. Ele escolhe como ponto de partida uma situação em que um homem, ao chegar a um cruzamento e se deparar com um automóvel em movimento vindo em sua direção, tem como opção parar ou morrer atropelado - "[...] o automóvel real é uma realidade, que poderá me atropelar ou não". (LUKÁCS, 2014, p. 26). O exemplo bastante simples, onde o problema ontológico aparece de modo muito grosseiro, tem o intuito de realçar o caráter de ser dos objetos, o dado primário da realidade. "Tomo deliberadamente um exemplo tão simples para mostrar como na nossa vida as diversas formas de ser estão sempre unidas entre elas e o inter-relacionamento constitui o dado primário.” (LUKÁCS, 2014, p. 24). 
Como natureza e sociedade se determinam mutuamente - daí, a afirmação de existir somente uma única ciência, a ciência da história - a reprodução imediata da vida cotidiana será sempre condicionada. Lukács (2014) cita como exemplo os desenhos rupestres dos homens da caverna que, ao contrário dos que afirmam ser as atividades espirituais puramente entidades da alma, revelou-se com o passar dos anos não um ato de pintura com finalidades estéticas, mas sim uma reação daquele homem ao meio externo, visto que a crença reinante era a de que tais representações render-lhe-iam uma boa caça ${ }^{25}$.

O outro ponto considerado em sua resposta diz respeito à metodologia. O filósofo acredita que, diferente da teoria kantiana do conhecimento que parte da matemática e da física newtoniana como fundamento do conhecimento, o caminho que se deve empreender é o da pesquisa genética (LUKÁCS, 2014). E aqui já se está no terreno dos problemas ontológicos: "[...] devemos tentar pesquisar as relações nas suas formas fenomênicas iniciais e ver em que condições estas formas fenomênicas podem tornar-se cada vez mais complexas e mediatizadas" ${ }^{\prime 26}$. (LUKÁCS, 2014, p. 25). Lukács (2014) está convencido de que, ao contrário da ciência que considera encontrar o melhor tipo de análise nas mais altas formas de objetivação, o caminho genético, da origem da ciência - que teria início com a escolha da pedra pelo homem primitivo ${ }^{27}$ - é o melhor para a compreensão dos fenômenos. Assim ele explica:

Creio que é muito mais seguro reconstituir o caminho da gênese da ciência começando pela escolha da primeira pedra utilizada para funções de trabalho e terminando com a ciência, ao invés de começar pela matemática superior e tentar retornar depois à escolha da pedra. Isto significa que, se quisermos compreender os fenômenos em sentido genético, o caminho da ontologia é inevitável [...]. Esta é então, por assim dizer, a justificação de por que eu considero essencial colocar-me a questão ontológica; e, do ponto de vista ontológico, as fronteiras entre as ciências têm um significado secundário. (LUKÁCS, 2014, p. 26, grifo do autor).

Holz dirige outra pergunta ao filósofo, e lhe indaga acerca de qual seria, em sentido estrito, o objeto da ontologia. Lukács (2014, p. 27, grifo nosso) diz que o objeto da ontologia "[...] é o que existe realmente [...]". A bela palavra ontologia, com a qual dizia ele em 1966 ainda estar se habituando, é assim incorporada ao universo mental do pensador húngaro. Ancorado no entendimento marxiano de que a única ciência que existe é a ciência da história, Lukács descobre na palavra ontologia o termo adequado para expressar a universalidade do marxismo ${ }^{28}$ (o elogio, com ressalvas, de Marx à Darwin é citado para reforçar o seu entendimento).

Em 1967, no Prefácio à reedição de História e Consciência de Classe, Lukács (2003) avalia que sua obra de 1923 acaba sendo a expressão de uma tendência presente no interior da tradição marxista que termina por se chocar frontalmente com "[...] os fundamentos da ontologia do marxismo". (LUKÁCS, 2003, p. 14). E isso porque, explica ele, tais tendências circunscrevem o marxismo exclusivamente no plano social e ainda se negam a reconhecer nele a expressa posição tomada diante da natureza. Assim se faz entender o velho Lukács (2003, p. 14):

Tenho em vista aquelas tendências que compreendem o marxismo exclusivamente como teoria social ou como filosofia social e rejeitam ou ignoram a tomada de posição nele contida sobre a natureza. Já antes da Primeira Guerra, marxistas de orientações bastante distintas, como Max Adler e Lunatscharski, defendiam essa tendência. Em nossos dias, deparamos com ela - provavelmente não sem a influência de História e consciência de classe - sobretudo no existencialismo francês e em seu ambiente intelectual.

A principal consequência dessa separação, na avaliação de Lukács (2003), é a perda da precisão no entendimento da práxis. A concepção geral de que apenas o conhecimento da sociedade e dos homens que nela vivem é filosoficamente relevante fazia com que, em sua obra de 1923 (LUKÁCS, 2003), o trabalho não aparecesse como mediador do metabolismo da sociedade com a natureza, já que esta era "[...] considerada como uma categoria social [...]" (LUKÁCS, 2003, p. 14). Com isso, "[...] a objetividade ontológica da natureza, que constitui o fundamento ôntico desse metabolismo, tem de desaparecer"29, escreve Lukács (2003, p. 16). Mas não é apenas tal objetividade que se apaga. Simultaneamente, a ação recíproca entre o trabalho material e o desenvolvimento do homem por meio da retroação da sua atividade também desvanece no interior dessa posição metodológica. De modo que estaria fora do escopo dela a compreensão marxiana de que "[...] até mesmo a "produção pela produção significa tão-somente o desenvolvimento das forças produtivas do homem, isto é, o desenvolvimento da riqueza da natureza humana como fim em si" [...]" "30,31 (LUKÁCS, 2003, p. 16, grifo do autor). Os efeitos dessa inobservância para uma correta apreensão do marxismo são assim ressaltados pelo filósofo húngaro:

A exploração capitalista perde esse lado objetivamente revolucionário, e não se compreende o fato de que, "embora esse desenvolvimento das capacidades do gênero homem se efetue, de início, à custa da maioria 
dos indivíduos e de certas classes, ele acaba por romper esse antagonismo e coincidir com o desenvolvimento de cada indivíduo". Não se compreende, portanto, que "o desenvolvimento superior da individualidade é conquistado apenas por um processo histórico em que os indivíduos são sacrificados" ${ }^{32}$. (LUKÁCS, 2003, p. 16, grifo do autor).

Na entrevista concedida em 1971 (LUKÁCS, 1999), a última pergunta dirigida pelos entrevistadores à Lukács foi a respeito de que, em qual medida, a tese sustentada por ele na Ontologia estaria fundada no autor d'O Capital. Em sua resposta, o filósofo afirma - dizendo ser essa a parte mais importante da teoria marxiana que Marx teria elaborado a tese segundo a qual a categoria fundamental de todo ser é que ele é histórico. "[...] Marx diz que só há uma única ciência, isto é, a história [...]"333 (LUKÁCS, 1999, p. 145). A unitariedade do ser, sustentada na afirmação marxiana proferida nos manuscritos parisienses de juventude segundo a qual só há uma única ciência (i. e., a história), estaria na base da sua visão última de tratar o marxismo como ontologia.

Segundo Marx, imagino a ontologia como a verdadeira filosofia baseada na história. Ora, historicamente, é indubitável que o ser inorgânico aparece primeiro e que dele - não sabemos como, mas sabemos mais ou menos quando - provém o ser orgânico, com suas formas animais e vegetais. E desse estado biológico resulta depois, através de passagens extremamente numerosas, aquilo que designamos como ser social humano, cuja essência é a posição teleológica dos homens, isto é, o trabalho. (LUKÁCS, 1999, p. 145, grifo nosso).

\section{Referências}

HEGEL, G. W. F. Fenomenologia do espirito. 2. ed. rev. Petrópolis: Vozes; Bragança Paulista: Universidade São Francisco, 2003.

LÊNIN, V. I. Cadernos filosóficos: sobre a dialética de Hegel. São Paulo: Boitempo, 2018.

LUKÁCS, G. A alma e as formas. Belo Horizonte: Autêntica, 2015.

LUKÁCS, G. Arte e sociedade: escritos estéticos 1932-1967. Rio de Janeiro: Editora UFRJ, 2009.

LUKÁCS, G. As bases ontológicas do pensamento e da atividade do homem. In: LUKÁCS, G. O jovem Marx e outros escritos de filosofia. Rio de Janeiro: Editora UFRJ, 2007. p. 225-245.

LUKÁCS, G. A teoria do romance: um ensaio histórico-filosófico sobre as formas da grande épica. São Paulo: Duas Cidades: 34, 2000. LUKÁCS, G. Conversando com Lukács: entrevistas a Léo Kofler, Wolfgang Abendroth e Hans Heinz Holz. São Paulo: Instituto Lukács, 2014.

LUKÁCS, G. El asalto a la razón: la trayectoria del irracionalismo desde Schelling hasta Hitler. 2. ed. Barcelona: Grijalbo, 1968a.

LUKÁCS, G. Ensaios sobre literatura. Rio de Janeiro: Civilização Brasileira, $1968 \mathrm{~b}$.

LUKÁCS, G. Estética 1. La peculiaridad de lo estético. Barcelona: Grijalbo, 1982. 4 v. (Coleção Instrumentos, 18-21).

LUKÁCS, G. História e consciência de classe: estudos sobre a dialética marxista. São Paulo: Martins Fontes, 2003.

LUKÁCS, G. Introdução a uma estética marxista: sobre a categoria da particularidade. Rio de Janeiro: Civilização Brasileira, 1978.

LUKÁCS, G. Marx e Engels como historiadores da literatura. São Paulo: Boitempo, 2016.

LUKÁCS, G. Marxismo e teoria da literatura. São Paulo: Expressão Popular, 2010a.

LUKÁCS, G. Nota à edição alemã. In: LUKÁCS, G. O romance histórico. São Paulo: Boitempo, 2011a. p. 27-29.

LUKÁCS, G. Nota do autor. In: LUKÁCS, G. Existencialismo ou marxismo? São Paulo: Senzala, 1967.

LUKÁCS, G. O jovem Hegel: e os problemas da sociedade capitalista. São Paulo: Boitempo, 2018a.

LUKÁCS, G. O romance histórico. São Paulo: Boitempo, 2011 b.

LUKÁCS, G. Para a ontologia do ser social. Maceió: Coletivo Veredas, 2018b. (Obras de Georg Lukács, v. 14)

LUKÁCS, G. Para uma ontologia do ser social I. São Paulo: Boitempo, 2012.

LUKÁCS, G. Para uma ontologia do ser social II. São Paulo: Boitempo, 2013.

LUKÁCS, G. Pensamento vivido: autobiografia em diálogo: entrevista a István Eõrsi e Erzsébet Vezér. São Paulo: Ad Hominem; Viçosa, MG: Editora da UFV, 1999.

LUKÁCS, G. Prolegômenos e para a ontologia do ser social. Maceió: Coletivo Veredas, 2018c. (Obras de Georg Lukács, v. 13)

LUKÁCS, G. Prolegômenos para uma ontologia do ser social: questões de princípios para uma ontologia hoje tornada possível. São Paulo: Boitempo, 2010b.

LUKÁCS, G. Socialismo e democratização: escritos políticos 1956-1971. Rio de Janeiro: Editora UFRJ, 2008.

LUKÁCS, G. Teses de Blum (extrato): a ditadura democrática. Temas de Ciências Humanas, São Paulo, v. 7, 1980.

MARCUSE, H. Ideologia da sociedade industrial. Rio de Janeiro: Zahar, 1969.

MARX, K. Manuscritos econômico-filosóficos. São Paulo: Boitempo, 2004.

MÉSZÁROS, I. Para além do capital: rumo a uma teoria da transição. São Paulo: Boitempo, 2011.

PAULO NETTO, J. Georg Lukács: um exílio na pós-modernidade. In: PINASSI, M. O.; LESSA, S. (org.). Lukács e a atualidade do marxismo. São Paulo: Boitempo, 2002. p. 77-101. 
PINASSI, M. O.; LESSA, S. (org.). Lukács e a atualidade do marxismo. São Paulo: Boitempo, 2002. SZABÓ, T. György Lukács, filosofo autonomo. 2. ed. Napoli: La Città del Sole, 2005.

TERTULIAN, N. Lukács e seus contemporâneos: coletânea de textos. São Paulo: Perspectiva, 2016.

VAISMAN, E.; VEDDA, M. (org.). Lukács: estética e ontologia. São Paulo: Alameda, 2014.

\section{Notas}

1 Enão apenas os escritos parisienses de 1844. Segundo informações do próprio autor em seu Meu Caminho para Marx (LUKÁCS, 2008), além das obras fundamentais do jovem Marx, teria exercido influência sobre ele a leitura dos Cadernos Filosóficos de Lenin (2018), publicados em 1929-30.

2 "[...] quis aproveitar meus conhecimentos nos domínios da literatura, da arte e da sua teoria para construir uma estética marxista", escreve ele em 1967 (LUKÁCS, 2003, p. 47).

3 Todos esses ensaios podem ser encontrados na recente edição publicada pela Boitempo de Marx e Engels como Historiadores da Literatura (LUCKÁCS, 2016), cuja reunião em um único volume sob esse título fora publicada no ano de 1952 para o público alemão.

4 Apesar de informar numa Nota à Edição Alemã (LUKÁCS, 2011a) que o livro fora publicado em russo logo após de concluído, no Pensamento Vivido (1999), o autor dá o seguinte depoimento: “[...] a publicação de O Romance Histórico era impossível na Rússia, apesar de tê-lo apresentado a uma editora". (LUKÁCS, 1999, p. 107).

5 Se, por um lado, a amizade com Usievic lhe garantia proteção, o filósofo não deixa de contabilizar também a seu favor a opção de se afastar do movimento húngaro. Diz ele: "Por outro, para minha sorte, eu já não desempenhava nenhum papel no partido húngaro e, assim, não havia nele ninguém que se recordasse de mim em particular". (LUKÁCS, 1999, p. 99).

6 Ver o Prefácio do ano de 1965 que abre a coletânea Marxismo e Teoria da Literatura (LUKÁCS, 2010a).

7 Esse livro foi publicado em alemão por uma editora de Zurique apenas no ano de 1948.

8 A primeira edição dessa obra vem a público em alemão no ano de 1953.

9 Lukács divergia dessa linha por defender a tese de que Hegel tratava-se do precursor de Marx (LUKÁCS, 2007).

10 Tais colocações servem, também, para contrastar a posição do filósofo húngaro em relação ao fenômeno stalinismo, ao menos no plano ideológico (estético, filosófico). "Aqui eu também era contra o dogma segundo o qual a filosofia moderna se fundaria exclusivamente na oposição entre materialismo e idealismo.” (LUKÁCS, 1999, p. 88).

11 Ainda sobre o seu processo de assimilação do marxismo, ele diz: "Não é possível experimentar só um pedaço do marxismo. Ou alguém realmente se converte ao marxismo-e sei que isso não é fácil, custou-me doze anos até que essa conversão tivesse êxito-, ou então pode-se também encarar muito bem o mundo de um ponto de vista burguês de esquerda". (LUKÁCS, 1999, p. 64, grifo nosso).

12 Em 1962, em seu Prefácio à edição de A Teoria do Romance, Lukács (2000, p. 13, grifo nosso) escreve: "Quando nós, com M. A. Lifschitz, em repúdio à sociologia vulgar, da mais variada extração, do período stalinista, tencionávamos desentranhar e aperfeiçoar a genuína estética de Marx, chegamos a um verdadeiro método histórico-sistemático".

13 “[...] Lenin expurgou preconceitos que, em vigor por decênios, envolviam os clássicos do marxismo; e este trabalho de depuração permitiu mostrar como a obra de Marx e de Engels era rica em noções até então ignoradas." (LUKÁCS, 2008, p. 48).

14 Lukács cita uma declaração em que Lenin ([19-], p. 264 apud LUKÁCS, 2008, p. 48) se contrapõe aos críticos marxistas da Nova Política Econômica (NEP), introduzida logo após a fase do chamado comunismo de guerra: "A Marx nunca ocorreu escrever uma só palavra sobre o tema: ele morreu sem nos deixar qualquer citação exata ou indicação irrefutável acerca dele. Cabe a nós resolver o problema".

15 Como o próprio já assinalava em 1957, ao comentar sobre a luta guerrilheira que combatera contra o dogmatismo: "Se hoje posso trabalhar numa estética e sonhar com a elaboração de uma ética, devo-o a esta luta". (LUKÁCS, 2008, p. 51).

16 Essa entrevista, cujo título seria A Autocrítica do Marxismo, teria sido publicada nos dias 24-25 de agosto de 1969, no Jornal do Brasil. Mais adiante, ainda respondendo à pergunta de Konder, ele diz: “As últimas elaborações teóricas realmente fundamentais realizadas no desenvolvimento histórico do marxismo foram as de Lenin”. (PINASSI; LESSA, 2002, p. 128, grifo nosso). Morto em 1971, o filósofo húngaro não poderia opinar sobre a obra de um dos seus discípulos, I. Mészáros (2011), intitulada Para Além do capital: rumo a uma teoria da transição, que busca abranger as transformações do capitalismo da segunda metade do século XX.

17 Marcuse (1969) escreveu, nos anos 1960, Ideologia da Sociedade Industrial, onde desenvolve as suas concepções de sociedade unidimensional etc.

18 “[...] que Stalin defendera, com razão, contra Trotski [...]” (LUKÁCS, 2008, p. 45).

19 DizLukács (2008, p. 45-46): "O próprio Stalin, homem muito sagaz, certamente levou em conta, na sua ação, sinais e momentos da nova situação. Contudo, não o fez com coerência, porque fazê-lo levaria à ruptura com os métodos do período do socialismo em um só país, ou seja, com os métodos objetivamente resultantes do permanente estado de perigo em que se encontrava uma Rússia industrialmente atrasada, métodos que o próprio Stalin havia levado bem além dos limites exigidos por esta situação".

20 O Prefácio é de dezembro de 1956. Nele, o autor anuncia que o estudo ora publicado havia sido planejado para ser um capítulo da obra sobre estética que preparava. Por razões de ordem estrutural, Lukács decide destacar o capítulo da obra geral e publicá-lo em separado, inclusive pelo problema da particularidade (tema central) ser um dos mais negligenciados; ele irá dizer ainda que, num sentido muito limitado, tal escrito pode ser considerado como prolegômenos à sua estética.

21 Ver Prefácio à edição húngara da coletânea Arte e Sociedade, publicada em sua pátria em 1968, disponível em Lukács (2009). 
22 Abreve Nota do Autor (LUKÁCS, 1967) de 1960 visa a atualizar a compreensão do seu autor entre a edição do trabalho, do ano de 1947, e a mais recente, notadamente em relação aos fatos anunciados no XX Congresso do PCUS por Krutchev, em 1956.

23 Há edições desse trabalho em castelhano, italiano e a versão original em língua alemã às quais se sugere, caso possível, o cotejamento. Uma edição bilingue (LUKÁCS, 2018b, 2018c), recém-lançada e coordenada por Sérgio Lessa, também se encontra disponível ao leitor brasileiro.

24 No Prefácio de 1962, ele escreve autocriticamente: "Em resumo: o autor da Teoria do Romance possuía uma concepção de mundo voltada a uma fusão de ética de "esquerda" e epistemologia de "direita" (ontologia etc.)". (LUKÁCS, 2000, p. 17). O filósofo ainda cita uma obra do seu contemporâneo Ernst Bloch, que revelava, em sua opinião, o anacronismo de sua postura teórica, ainda caracterizada por aquela fusão: Questões Filosóficas Fundamentais: para uma ontologia do ainda-não-ser, publicada em Frankfurt em 1961 (LUKÁCS, 2000). O dado a frisaré o uso por Bloch da expressão ontologia, algo indicativo da recorrência à essa expressão naquela quadra histórica.

25 As inscrições a que o autor se refere teriam sido encontradas na França meridional e na Espanha (LUKÁCS, 2014).

26 O que, diz ele, em certo sentido, não deixaria de desagradar o cientista.

27 "Se me reporto a um tempo anterior à produção dos instrumentos de trabalho e penso em uma época na qual o homem primitivo, para satisfazer a certas funções, limitava-se a recolher as pedras mais adequadas, posso imaginar esse homem primitivo que diz, observando duas pedras: estaé própria para arrancar um ramo e esta não [...]. Com esta escolha da pedra inicial começa a ciência.” (LUKÁCS, 2014, p. 26).

28 Lukács cita e ressalta o pioneirismo de Nicolai Hartmann na colocação do problema do complexo enquanto existente primário. Em Para uma Ontologia do Ser Social I, Lukács (2012) dedica um capítulo à Hartmann e à análise da ontologia deste, citando a sua obra Zur Grundlegung der Ontologie [Sobre a Fundamentação da Ontologia]. Da seguinte forma o pensador húngaro expressa o seu juízo sobre a ontologia de Hartmann: "Na ontologia de Hartmann e em seu método, os objetos da velha metafísica ou não desempenham nenhum papel ou emergem em contextos temáticos e metodológicos tão transformados que jamais se poderá falar de qualquer semelhança ou continuidade. Os problemas clássicos naturalmente são tematizados até com bastante frequência. Porém, como Hartmann constrói sua ontologia justamente a partir de "baixo", uma vez que esta nãoé projetada como uma philosophia ultima, mas como uma philosophia prima, surge por obra dele uma disciplina filosófica nova e isenta, autêntica e-dentro dos limites ainda a serem mostrados [referência ao tópico posterior de sua análise]-fecunda [...]" (LUKÁCS, 2012, p. 133, grifo do autor). Nicolas Tertulian (VAISMAN; VEDDA, 2014) apresenta aspectos da interlocução entre Lukács e Hartmann em seu ensaio György Lukács e a Reconstrução da Ontologia na Filosofia Contemporânea. Nele, inclusive, Tertulian menciona a posição posterior de Hans Heinz Holz (VAISMAN; VEDDA, 2014). Noutro ensaio, Nicolai Hartmann e György Lukács: uma aliança fecunda, o filósofo de origem romena também trata mais detidamente daquela interlocução mencionada (TERTULIAN, 2016). Nesta coletânea (TERTULIAN, 2016), há ensaios profícuos onde o autor esforça-se para situar-também-Lukács no debate filosófico com outras matrizes do pensamento da atualidade, tais como Heidegger eAdorno.

29 "Isso demonstra, por um lado, que é precisamente a concepção materialista da natureza a separar de maneira radical a visão socialista do mundo da visão burguesa; que se esquivar desse complexo mitiga a discussão filosófica e impede, por exemplo, a elaboração precisa do conceito marxista de práxis. Por outro lado, essa aparente elevação metodológica das categorias sociais atua desfavoravelmente às suas autênticas funções cognitivas; sua característica especificamente marxista é enfraquecida, e, muitas vezes, seu real avanço para além do pensamento é inconscientemente anulado." (LUKÁCS, 2003, p. 15, grifo nosso).

30 Esse entendimento estaria vedado àquela posição metodológica, para a qual certos aspectos do marxismo estariam obscurecidos: “[...] os pilares reais e mais importantes da visão marxista do mundo desaparecem, e a tentativa de tirar, com extrema radicalidade, as últimas conclusões revolucionárias do marxismo permanece sem sua autêntica justificação econômica”. (LUKÁCS, 2003,p. 16).

31 Theorien über den Mehrwert [Teoria sobre a Mais-Valia], II, MEW 26, 2, p. III.

32 Ver nota 31.

33 Em contraste com a velha filosofia, ele diz acerca do marxismo: "Não é que a história se passe no interior do sistema de categorias, mas sim que a história é a transformação do sistema de categorias. As categorias são, portanto, formas de ser”. (LUKÁCS, 1999, p. 146).

\section{Rogério Castro}

rcastro.liceu@gmail.com

Doutorado em Serviço Social pela Universidade Federal do Rio de Janeiro (UFRJ)

Professor vinculado ao Mestrado Acadêmico em Serviço Social, Trabalho e Questão Social (MASS) da Universidade Estadual do Ceará (UECE) através do Programa Nacional de Pós-Doutorado da Coordenação de Aperfeiçoamento de Pessoal de Nível Superior (CAPES)

\section{UECE}

Mestrado Acadêmico em Serviço Social

Av. Dr. Silas Munguba, 1700 - Campus do Itaperi

Fortaleza - Ceará - Brasil

CEP: 60.740-903 


\section{Agradecimentos}

À Coordenação de Aperfeiçoamento de Pessoal de Nível Superior (CAPES), ao professor emérito José Paulo Netto (UFRJ) pela honrosa orientação nos dada no doutoramento e à professora Liana Brito (MASS/UECE), pelo aprendizado, singelo apoio e incentivo.

\section{Agência financiadora}

Programa Nacional de Pós-Doutorado da Coordenação de Aperfeiçoamento de Pessoal de Nível Superior (PNPD/CAPES).

Processo: 88882.315014/2019-01.

Período de vigência: agosto de 2018 a julho de 2023.

\section{Contribuições dos autores}

Não se aplica.

Aprovação por Comitê de Ética e consentimento para participação

Não se aplica.

\section{Consentimento para publicação}

Não se aplica.

\section{Conflito de interesses}

Não há conflito de interesses. 